ARTIKEL

\title{
MANAJEMEN PESANTREN DALAM PEMBANGUNAN DESA
}

\author{
Mohammad Mustari \\ Kementerian Pendidikan dan Kebudayaan Indonesia \\ Dedeng Yusuf Maolani \\ UIN SGD Bandung \\ m.mustary.phd@gmail.com
}

\begin{abstract}
The purpose of this study is to make a systematic analysis of the role and contribution of pesantrens in the development of rural areas, especially in Kab. Tasikmalaya whose number has reached 761 pesantrens. This study uses multiple case study methods. The cases consist of six pesantrens (three large Islamic boarding schools and three small Islamic boarding schools), all located in Kab. Tasikmalaya. The selection of pesantrens was due to representing three categories: traditional, modern and combination. Interview, observation and document analysis are used to collect data. Face-to-face interviews use a list of questions developed for this study. The study findings show that all pesantrens design themselves and implement development plans, both for the pesantrens themselves and for village development, which is their social environment, because most of the pesantrens are in rural areas.
\end{abstract}

Keywords: Community Education, Education Management, Islamic Boarding Schools, Village Development

\begin{abstract}
Abstrak
Tujuan kajian ini adalah untuk membuat analisis sistematis yang mendalam terhadap peran dan kontribusi pesantren dalam pembangunan wilayah perdesaan, terutama di Kab. Tasikmalaya yang jumlahnya telah mencapai 761 pesantren. Kajian ini menggunakan metode kajian kasus berganda. Kasus-kasusnya terdiri dari enam pesantren (tiga pesantren besar dan tiga pesantren kecil), semuanya berlokasi di Kab. Tasikmalaya. Pemilihan pesantren-pesantren itu disebabkan karena mewakili dari tiga kategori: tradisional, modern, dan kombinasi. Wawancara, pengamatan, dan analisis dokumen digunakan untuk mengumpulkan data. Wawancara tatap muka memakai daftar pertanyaan yang dikembangkan untuk kajian ini. Temuan kajian menunjukkan bahwa semua pesantren merancang sendiri dan melaksanakan rencana pembangunan, baik untuk di dalam pesantren itu sendiri maupun untuk pembangunan desa, yang menjadi lingkungan sosialnya,karena kebanyakan pesantren itu berada di perdesaan.
\end{abstract}

Kata kunci: Pendidikan Komunitas, Manajemen Pendidikan, Pesantren, Pembangunan Desa

\section{A. Pendahuluan}

Indonesia mempunyai penduduk yang terdiri dari berbagai etnis, budaya, bahasa, dan agama. Namun mayoritas penduduknya, sekitar 85 persen, terdiri dari 
masyarakat Islam (BPS, 2014). Agama Islam telah tersebar di Indonesia pada abad ke-12; dan berbarengan dengan itu, telah ada sejak dahulu sistem pendidikan nonformal Islam di masyarakat Indonesia dalam bentuk institusi masjid, surau, dan pesantren. Posisi agama dan institusi Islam di Indonesia amat tersebar dan kokoh melalui institusi pendidikan seperti pesantren hingga meliputi ke semua 33 provinsi. Institusi pesantren kini berjumlah 16,015 buah yang ada di seluruh pelosok daerah (kabupaten/kota) di Indonesia (Departemen Agama, 2016).

Institusi pesantren ini secara umum menganut satu falsafah pemikiran bahwa pendidikan adalah untuk pembentukan insan yang syumul, bukannya falsafah pembentukan modal insan atau pembangunan sumber daya manusia biasa. Insan yang syumul ialah insan yang komprehensif, meliputi aspek spiritual, intelektual, vokasional, sosial, fisik, budaya, dan emosi, dan hal ini dapat digarap oleh institusi masjid dan pesantren. Dengan itu, telah ada pertentangan ideologi tentang pendidikan di Indonesia: satu yang berlandaskan falsafah Islam dan satu lagi berlandaskan falsafah utilitarian kapitalis Barat sejak kedatangan kolonial Belanda pada abad ke-16 (Abdullah, 1986).

Pada sudut etimologi, "pesantren" dan kata dasar "santri" berasal dari Bahasa Tamil yang bermakna "guru mengaji”. Sumber lain menyebutkan bahwa kata itu berasal dari Bahasa India "shastri" dari akar kata "shastra" yang bermakna "buku-buku suci”, "buku-buku agama", atau "buku-buku tentang ilmu pengetahuan”. Di luar pulau Jawa institusi pendidikan ini disebut dengan nama lain, seperti surau (di Sumatra Barat), dayah (di Aceh), dan pondok (di daerah lain) (Ensiklopedi Islam, j. IV, 1994). Dalam penggunaannya di Indonesia hari ini dua istilah "pondok" (Arab: asrama atau hotel) dan "pesantren" seringkali dapat ditukar-tukarkan penggunaannya, bahkan seringkali digabung menjadi "pondok pesantren” yang biasa pula disingkat menjadi "ponpes" (Mansurnoor, 1990).

Menurut Dhofier (1983), perkataan pesantren berasal dari kata "santri" itu sendiri, yang kemudian diberi awalan "pe" dan akhiran "an", yang berarti tempat tinggal para santri (murid). Demikianlah, sehingga secara ringkasnya pesantren disebut sebagai asrama tempat santri atau tempat murid-murid belajar mengaji dan sebagainya (Kamus Besar Bahasa Indonesia, 1995). 
ARTIKEL

Berdasarkan data Departemen Agama tahun 2015/2016, di setiap provinsi di Indonesia telah ada institusi pesantren. Jumlahnya 16,015 pesantren dengan 3,190,394 orang santri (murid) dan 276,223 tenaga pengajar dengan 44,450 orang kyai. Jumlah pesantren pada setiap provinsi bervariasi antara 12 sampai dengan 3684 pesantren (Depag, 2016).

Kab. Tasikmalaya yang memiliki 39 kecamatandan 351 desa/kelurahan mempunyai lebih dari satu buah pesantren di hampir setiap desa. Dengan demikian, Kab. Tasikmalaya layak disebut sebagai "kota santri." Di antara pesantren-pesantren besar yang terdapat di Kab. Tasikmalaya, yaitu terbesar dan dihuni oleh lebih dari 500 orang santri, adalah: Pesantren Cipasung di Singaparna; Pesantren Miftahul Huda di Manonjaya; dan Pesantren Suryalaya diPagerageung.

\section{B. Tinjauan Teori}

Dari segi teoretis, masalah utama kajian ini adalah untuk melihat sejauh mana kesahihan dan aplikasi teori dualisme serta teori modernisasi, teori perubahan sosial, dan teori kepemimpinan pembangunan oleh kyai-kyai dalam konteks peranan dan fungsi pesantren dalam pembangunan masyarakat desa di Indonesia.

Dengan memusatkan perhatian pada kasus pesantren-pesantren di Kab. Tasikmalaya, masalah kajian secara rinci dirumuskan dalam pertanyaan penelitian berikut: "Bagaimakah pola manajemen pesantren sebagai institusi sosial dan pembangunan masyarakat?”

Kajian ini mempunyai beberapa tujuan utama, yaitu:

1. Untuk meneliti keadaan manajemenpesantren di Kab. Tasikmalaya.

2. Untuk memperolehpandangan masyarakat tentang relevansi dan citra pesantren, baik menurut pandangan masyarakat di dalam pesantren maupun menurut masyarakat di sekelilingnya.

3. Untuk mendeskripsikan secara analitisperanan dan potensi pesantren dan lingkungannya, sehubungan dengan kemungkinan peranan pesantren sebagai institusi agen perubahan sosial (social change) di daerah perdesaan, yang mampu berdiri sendiri sekaligus berperanan dalam pembangunan desa.

Bidang penelitian ini adalah sosiologi pendidikan, yaitu "analisis prosesproses sosiologis yang terlibat dalam institusi pendidikan” (Stalcup, 1968).Penelitian 
ini membatasi diri hanya pada aspek dan perkara yang berhubungan dengan pola yang dikembangkan pesantren dalam melakukan tindakan partisipatif pelaksanaan pembangunan masyarakat perdesaan. Demikianlah yang terutama diteliti ialah peranan institusi pesantren itu sendiri dalam pembangunan desa. Hal ini tentu saja melibatkan "berbagai masalah struktur fungsi dan analisis fungsi dalam hubungannya dengan sistem sosial keseluruhan dan masyarakat-mikro sekolah.” (Morrish, 1978).Oleh karena itu, penelitian ini mau tidak mau akan mengungkap lebih jauh tentang model pendidikan yang dikembangkannya dan juga keterlibatan kyai dalam dualisme tradisionalisme dan modernisme.

Penelitian ini menyelidiki pembangunan sosial yang merupakan suatu program kesejahteraan atau bantuan bagi orang miskin melalui pemenuhan keperluan dasarnya, yang mencakup bukan hanya kesempatan memperoleh pendapatan, melainkan juga akses terhadap pelayanan publik, seperti pendidikan, kesehatan, perumahan, transportasi, air bersih, dll. (Korten dan Alfonso, 1981). Dengan demikian, konsepsi pembangunan di sini ialah konsepsi “pembangunan integratif”.

Oleh karena itu, selain menggunakan indikator-indikator pembangunan yang sudah diukur oleh pihak pemerintah, terutamanya melalui Badan Pusat Statistik (BPS), kajian ini menggunakan survey pendapat umum (public opinion survey) untuk memperolehdata mengenai kesan pesantren terhadap pembangunan desa.

Adapun mengenai pengumpulan data yang dilakukan dalam penelitian ini dapat diterangkan sebagai berikut:

1. Untuk kajian komprehensif terhadap pesantren-pesantren yang dijadikan kasus, digunakan wawancara mendalam (in-depth interview) dan pengamatan.

2. Sedangkan untuk mendapatkan data-data lingkungan, terutama yang bersifat fisik, dilakukan pengumpulan data-data sekunder khususnya dari institusiinstitusi pemerintah tingkat kabupaten, provinsi, dan pusat.

Maka, kajian menggunakan dua kategori instrumen, yaitu instrumen wawancara dan pengamatan. Ini secara langsung memastikan reliabilitas data dan temuan kajian secara triangulasi.

Populasi didefinisikan sebagai satu kumpulan peserta potensial yang mana hasil kajiannya akan dijadikan generalisasi (Salkind, 2000) atau seluruh kumpulan yang akan dikaji (Chua, 2006). 
Populasi penelitian ini adalah pesantren yang ada di Kabupaten Tasikmalaya, Jawa Barat, yang berjumlah sekitar 761 pesantren, tersebar hampir di seluruh desa yang ada, atau berada di setiap kecamatan (mukim) di Kabupaten ini. Dari populasi ini yang dijadikan sampel kasus ialah pesantren yang dianggap representatif sesuai dengan topik penelitian. Dalam hal ini pesantren di Kab. Tasikmalaya terbagi ke dalam tiga jenis pesantren, yaitu pesantren Modern, pesantren Tradisional, dan pesantren Kombinasi (campuran jenis Modern dan Tradisional). Dari segi jumlah, pesantren juga dapat dibagi menjadi dua jenis, yaitu pesantren Besar (mempunyai santri lebih dari 300 orang) dan pesantren Kecil (mempunyai santri kurang dari 300 orang), seperti dijelaskan dalam bagan di bawah ini.

\section{Bagan 1}

\section{Pembagian Pesantren Menurut Kualitas dan Kuantitas}

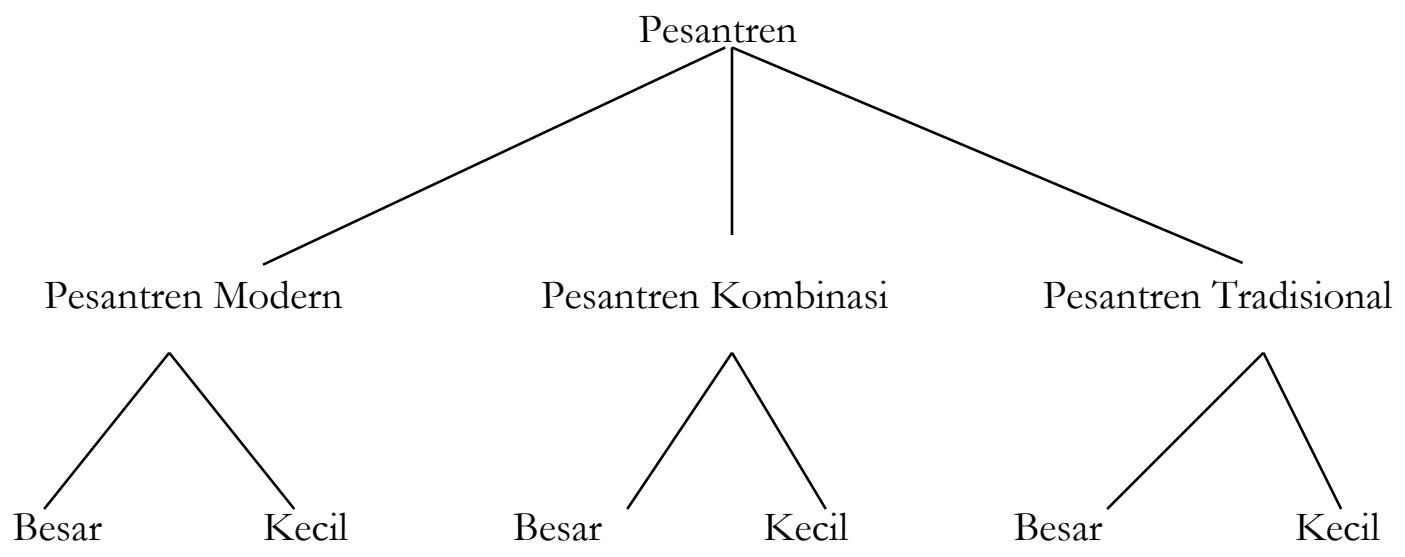

Dari sekitar 761 pesantren yang ada di Kab. Tasikmalaya, diambil enam pesantren untuk mewakili masing-masing kategori seperti tersebut di atas, yaitu:

1. Pesantren Miftahul Huda, Manonjaya yang mewakili jenis pesantren Tradisional Besar.

2. Pesantren Asy-Syahidiyah, Cisayong yang mewakili jenis pesantren Tradisional Kecil.

3. Pesantren Al-Furqon, Singaparna yang mewakili jenis pesantren Modern Besar.

4. Pesantren Persis, Rajapolah yang mewakili jenis pesantren Modern Kecil.

5. Pesantren Suryalaya, Pagerageung yang mewakili jenis pesantren Kombinasi Besar. 
6. Pesantren Ar-Riyadh, Leuwisari yang mewakili jenis pesantren Kombinasi Kecil.

Pemilihan pesantren dilakukan secara sengaja (purposive), yaitu pemilihan yang disebabkan kasus-kasus yang kaya informasi (information-rich cases) (Patton, 2002). Sebenarnya jika diukur secara kuantitatif, 6 pesantren di atas tidak dapat dikatakan tepat untuk mewakili 761 pesantren yang ada dan terdaftar di daerah Kab. Tasikmalaya. Tapi karena kebanyakan pesantren di Tasikmalaya tersebut di atas tergolong pesantren-pesantren yang memiliki kondisi yang sama dan ciri-ciri yang sama pula, maka pengambilan kasus pesantren tidak perlu didasarkan pada rumus $20 \%$ dari populasi. Pemilihan kasus didasarkan untuk memperoleh variasi yang representatif, yaitu dua pesantren tergolong pada pesantren Tradisional besar dan kecil (PP. Miftahul Huda dan PP. Asy-Syahidiyah), dua pesantren tergolong pada pesantren Modernbaik besar dan kecil (PP. Al-Furqon dan PP. Persis Rajapolah), dan dua pesantren tergolong pada pesantren Kombinasi baik besar dan kecil (PP. Suryalaya dan PP. Ar-Riyadh). Demikianlah, 6 pesantren di atas dianggap cukup mewakili berbagai variasi dari pesantren-pesantren yang ada di Kab. Tasikmalaya.

Selain itu, daftarisian digunakan untuk mendapatkan gambaran umum keadaan pesantren dan untuk memenuhi hasrat triangulasi data. Adapun responden bagi daftarisian ini terdiri atas 3 kelompok utama, yaitu:

1. Kelompok orang-orang yang ada di pesantren, yaitu kyai, santri dan ustadz.

2. Kelompok masyarakat yang terdiri dari pemimpin resmi (kepala desa dan camat), pemimpin informal (tokoh-tokoh masyarakat) serta orang awam (petani, pedagang, buruh, pegawai, dan sebagainya).

3. Kelompok masyarakat yang ada hubungannya dengan pesantren, yaitu alumni dan orang tua santri.

Adapun jumlah dan perincian responden dapatlah dilihat pada tabel1. berikut:

Tabel 1

Responden Daftar Isian Penelitian

\begin{tabular}{|l|l|c|c|}
\hline \multirow{2}{*}{ Kelompok } & \multirow{2}{*}{ Jenis Responden } & \multicolumn{2}{|c|}{ Jumlah } \\
\cline { 3 - 4 } & & Responden & Kelompok \\
\hline Kelompok & Kyai & 4 & 18 \\
Pesantren & Ustadz & 4 & \\
& Santri & 10 & \\
\hline
\end{tabular}


ARTIKEL

\begin{tabular}{|l|l|c|c|}
\hline Kelompok & Pemimpin Resmi & 4 & 9 \\
Masyarakat & Pemimpin Informal & 2 & \\
& Orang Awam & 3 & 10 \\
\hline Kelompok Terkait & Orang tua & 5 & 15 \\
dgn Pesantren & Alumni & $\mathbf{4 2}$ & $\mathbf{4 2}$ \\
\hline Jumlah responden per kecamatan & \multicolumn{2}{|c|}{$\mathbf{2 5 2}$} \\
\hline Jumlah responden seluruhnya (6 & \\
kecamatan)
\end{tabular}

Pengambilan responden ditentukan dengan metode "quota", yaitu pemilihan subjek berdasarkan kategori-kategori yang dianggap ada dalam populasi (Chua, 2006) berdasarkan petunjuk dari kepala desa, camat, pimpinan pesantren dan tokoh masyarakat.

\section{Hasil dan Pembahasan}

\section{Gambaran Umum Pesantren di Tasikmalaya}

Kab. Tasikmalaya, sebagai lokasi penelitian ini, adalah salah satu dari 25 kabupaten/kota dalam wilayah administrasi Provinsi Jawa Barat, Indonesia. Kabupaten ini terletak kurang lebih 90 kilometerdari ibukota provinsi (Bandung) ke arah tenggara, atau sekitar $380 \mathrm{~km}$ sebelah tenggara Jakarta. Sebelah utara berbatasan dengan Kab.Ciamis dan Kota Tasikmalaya, selatan dengan Samudera Indonesia, sebelah barat dengan Kab. Garut, dan sebelah timur dengan Kab. Ciamis. Ibukota Kab. Tasikmalaya ialah Singaparna. Kabupaten yang luasnya 2,712,52km2 ini merupakan daerah pergunungan dengan puncaknya di Gunung Galunggung dan Gunung Talagabodas (Atlas Provinsi, 2016).

Jumlah penduduk Kab. Tasikmalaya pada tahun 2015adalah 1,686,633 orang dengan kepadatan 615manusia/km2 (Kabupaten Tasikmalaya Dalam Angka, 2016).Mata pencaharian sebagian besar penduduknya adalah pada sektor pertanian dan ternakan; yang lainnya ialah pada sektor-sektor perdagangan, jasa (services), pegawaipemerintah, pekerja swasta, dan lain-lain. Yang unik untuk Tasikmalaya adalah banyaknya industri kecil (cottage industry) yang menghasilkan pakaian, kain berhias, sandal kayu (kelom), dan kraf tangan (Pikiran Rakyat, 15 April 2017).

Berdasarkansensus penduduk tahun 2015, pemeluk agama di Kab. Tasikmalaya $99.97 \%$ beragama Islam $(1,686,098)$; selebihnya adalah mereka yang 
ARTIKEL

menganut agama Kristen Protestant yaitu 149 orang (0.001\%), Katholik 246 orang (0.014\%), Hindu 91 orang (0.005\%), Buddha 8 orang (0.0005\%), dan lainnya 41 orang $(0.002 \%)$. Berdasarkan data ini, masyarakat Tasikmalaya mempunyai pegangan agama. Hal ini terbukti dengan banyaknya institusi pendidikan yang bercorak keagamaan (Islam), yaitupesantren.

Kab. Tasikmalaya yang memiliki 39 kecamatan (mukim) dan 348 desa mempunyai lebih dari sebuah pesantren di hampir setiap desa. Dengan demikian, Kab. Tasikmalaya layak dan sesuai disebut sebagai "kota santri." Di antara pesantren besar yang terdapat di Kab. Tasikmalaya yang dihuni oleh ribuan orang santri adalah Pesantren Cipasung di Singaparna, Pesantren Miftahul Huda di Manonjaya, dan Pesantren Suryalaya di Pagerageung.

\section{Potensi dan Arah Perkembangan Pesantren}

Di Tasikmalaya khususnya, nampaknya, pesantren masih merupakan suatu institusi yang cukup berpengaruh di kalangan masyarakat. Di tengah-tengah dunia modern, pesantren memang tetap menjadi rujukan dalam menentukan sesuatu tindakan itu benar atau salah. Demikianlah sehingga masalah-masalah pembangunan seperti masalah $\mathrm{KB}($ Keluarga Berencana), fatwa dari pesantren lah yang dicari.

Memang pesantren mempunyai kemungkinan untuk tetap hidup dan berkembang. Ini dibuktikan dengan adanya cukup banyak pesantren (761 pesantren), Madrasah Tsanawiyah Swasta (138 madrasah), dan Madrasah Aliyah Swasta (39 madrasah) yang dibangun dan didukung oleh masyarakat. Jika dibandingkan dengan jumlah sekolah swasta (SMP 45 sekolah; SMA 24 sekolah; dan SMK 22 sekolah) dan jumlah sekolah negeri (pemerintah) (yaitu, SMPN 107 sekolah; SMAN 14 sekolah; dan SMKN 2 sekolah), ini menunjukkan bahwa tingkat partisipasi masyarakat dengan motivasi agama di bidang pendidikan cukup tinggi (Kabupaten Tasikmalaya Dalam Angka, 2016).

Jika dilihat pada jumlah persekolahan menengah di atas, pesantren di Kab. Tasikmalaya adalah terbanyak, yaitu 761 pesantren. Sekolah menengah pula adalah 214 sekolah. Sementara madrasah menengah ialah 195 (18 madrasah negeri dan 177 madrasah swasta).(Kabupaten Tasikmalaya Dalam Angka, 2016). 
Dari segi jumlah murid, pesantren pun masih menempati peringkat terbanyak, yaitu 68,630 santri. Ia lebih tinggi berbanding jumlah murid sekolah menengah, yaitu 63,697 (SMP 48,065; SMA 10,839; dan SMK 4,793). Sementara murid madrasah berjumlah 38,737 (MTs 29,888 dan MA 8,849).(Kabupaten Tasikmalaya Dalam Angka, 2016).

Data di atas menunjukkan bagaimana pesantren telah menjadi tempat pendidikan utama. Namun, sebagai institusi pendidikan, kini pesantren tidak sendirian. Sudah banyak sekolah dan madrasah yang didirikan untuk memenuhi keperluan masyarakat. Yang kemudian menjadi pertanyaan ialah: apakah pesantren masih mempunyai daya tarik sedemikian besar terhadap masyarakat sehingga anggota-anggota masyarakat bersedia atau mau mengirimkan anak-anak mereka ke pesantren? Demikian itu karena pada zaman ini orang memerlukan pengetahuan minimal seperti tulis baca huruf latin, berhitung, Bahasa Indonesia, Bahasa Inggris, dan sebagainya. Oleh karena itu, pendidikan pesantren tradisional akan mempunyai arti apabila dilengkapi dengan pendidikan am.

Ada data yang cukup menyedihkan dalam perkembangan pesantren di Kab. Tasikmalaya. Yaitubahwa sementara jumlah pesantren dan jumlah kyai bertambah, jumlah santri pula yang menurun sangat drastis. Pada tahun 2013 jumlah pesantren ialah 529 pesantren dan jumlah kyai ialah 5,125 orang kyai. Pada tahun 2016 jumlahnya bertambah menjadi: pesantren 761 dan kyai 5.246. Tetapi pada santri tahun 2013 semuanya berjumlah 215,798 santri dan pada tahun 2016 menjadi 67,647.

Begitulah, nampaknya orang tua sudah banyak yang tak lagi tertarik untuk menyekolahkan anaknya ke pesantren. Sesuatu yang sangat mungkin adalah bahwa pesantren agak lambat dalam mengikuti perkembangan dunia kerja, sehingga ia banyak ditinggalkan.

Satu-satunya harapan pada pesantren adalah dengan membuat jawaban yang tepat atas tuntutan masyarakat (social demand) tersebut. Yaitu, misalnya, dengan membuat pesantren yang bercampur dengan sekolah, atau apa yang dikatakan pesantren kombinasi. Sebab, perkembangan nasional juga menunjukkan bahwa jenis pesantren tradisional (Salafi) dan modern (Khalafi) itu menurun sementara jumlah jenis pesantren Kombinasi menaik. Dari data tahun 2013 pesantren Kombinasi adalah 6,596 sementara tahun 2016 berjumlah 8,206. Pada pesantren Salafi, tahun 
ARTIKEL

2013 ia berjumlah 4,692 sedangkan pada tahun 2016 ia berjumlah 3,981. Pada pesantren Khalafi pula, 2013 ia berjumlah 3,368 sedangkan tahun 2016 ia berjumlah 2,824. (Statistik Pendidikan Agama dan Keagamaan Tabun Pelajaran 2015-2016, 2016).

Walaupun secara nasional Pesantren Kombinasi ini menjadi trend baru, di Kab. Tasikmalaya sendiri, pesantren jenis ini masihlah belum banyak bermunculan. Dari 761 pesantren, pesantren Kombinasi hanyalah berjumlah 35 pesantren, hampir sama dengan pesantren modern (Khalafi), yaitu 31 pesantren. Sisanya masihlah pesantren tradisional (Salafi), yaitu 695 pesantren. (Kandepag Tasikmalaya, 2016). Barangkali disebabkan bahwa di Tasikmalaya ini banyak orang masih menganggap bahwa pesantren yang terbaik adalah pesantren tradisional, yang telah banyak melahirkan para ulama.

Betapapun, dalam kenyataannya, beberapa pesantren seperti Pesantren Persis Rajapolah dan Pesantren Ar-Riyadh Leuwisari tahun 2000-an telah mendirikan SMA (Sekolah Menengah Atas) dan SMK (Sekolah Menengah Kejuruan). Jadi dengan tidak mengurangi arti pengajian kitab, pesantren-pesantren yang ada bisa dikembangkan menjadi institusi pendidikan yang juga menyediakan pendidikan dengan sistem klasikal, baik yang berbentuk madrasah (MI, MTs, dan MA) ataupun sekolah (SD, SMP, SMA atau SMK). Inilah yang disebut dengan Pesantren Kombinasi. Kecenderungan menjadi pesantren kombinasi inilah yang nampaknya semakin jelas bermunculan. Demikian karena pada pesantren kombinasi tersebut terdapat dua tujuan dalam satu institusi pendidikan, yaitu tujuan kehidupan dunia dan kehidupan akhirat. Dengan menerima sistem-sistem pendidikan sekolah dan madrasah, pesantren-pesantren tersebut memang tidak mau melepaskan gelar yang sudah lama disandangnya, yaitu sebagai pusat budaya.

\section{Perkembangan Pesantren di Tasikmalaya}

Apabila dibuat klasifikasi, memang pesantren itu berbeda-beda dari segi riwayat. Ada pesantren yang berasal dari kharisma kyai seperti Pesantren Miftahul Huda, Asy-Syahidiyah, Ar-Riyadh, dan Suryalaya.Ada pula pesantren yang berasal dari suatu organisasi keagamaan seperti Al-Furqon dari Muhammadiyah dan Pesantren Persis.Namun sebagian besarnya ialah bahwa pesantren itu didirikan lebih dulu dari sekolah formal pemerintah. Demikian karena pesantren adalah upaya sosialisasi 
pendidikan kepada generasi muda oleh generasi sebelumnya yang mengutamakan ilmu agama dan budaya Islam. Dan usaha tersebut tidak terbatas pada ada atau tidak adanya fasilitas. Maka, kegiatan pengajian Islam itu sudah dilakukan sebelum pesantren didirikan. Setelah pesantren didirikan, barulah sekolah atau madrasah juga dibangun.

Walaupun begitu, ada pula yang sejak awal sudah mau menerapkan sekolah di pesantren. Dengan demikian, pesantren dan sekolah adalah sesuatu yang identik. Hal ini dialami, misalnya, oleh pesantren modern seperti Al-Furqon, Singaparna.Bedanya ialah bahwa sekolah itu murid sekolah pulang ke rumah, sementara di pesantren, murid sekolah itu terus mengikuti program kepesantrenan.

Ada hal lain dari tradisi pesantren ini, yaitu tradisi ikutan pada induk. Dalam hal ini pesantren awal dapat disebut sebagai model bagi pesantren selanjutnya, dalam satu jenis model. Jelasnya, apabila seorang santri telah merasa cukup mampu untuk mendirikan pesantren, maka ia mendirikannya di tempat lain, seperti di kampungnya sendiri dengan mengambil model pesantren tempat ia belajar dahulu. Hal ini misalnya banyak dilakukan oleh santri-santri keluaran Miftahul Huda. Maka tidak heranlah jika Pesantren Miftahul Huda mengakui bahwasudah sekitar 1000 pesantren telah dikeluarkan oleh pesantren tersebut. Menurut salah seorang ustadznya, ciri pesantren yang menginduk kepada Miftahul Huda ialah selalunya ada nama 'Miftah' pada awal nama pesantren anaknya tersebut, seperti 'Miftahul Ulum', 'Miftahul Jannah', dan sebagainya. Atau ada nama 'Huda' pada akhir nama pesantren anaknya tersebut, seperti 'Manbaul Huda', 'Thoriqul Huda', dan lain-lain. Atau bahkan tidak jarang ada yang menamai pesantrennya sebagai 'Miftahul Huda' sendiri.

Pengindukan seperti itu juga terjadi di pesantren-pesantren lain. Pesantren Ar-Riyadh, misalnya, mengaku sudah ada 70 pesantren yang didirikan oleh santrisantri keluaran pesantren tersebut. Pesantren Asy-Syahidiyah juga mengaku bahwasudah ada 40 pesantren yang didirikan oleh para santri alumni pesantren tersebut.

Namun demikian, tidak semua pesantren mempunyai tradisi pengindukan seperti itu. Pesantren Suryalaya, misalnya, tidak banyak alumninya yang membuat pesantren. Demikian karena fokus pendidikan Suryalaya tidak untuk menghasilkan ulama yang menguasai banyak ilmu dan menjadi seorang pengurus pesantren. Fokus 
Suryalaya adalah menyebarluaskan faham tarekat, yaitu Tariqat Naqsabandiyah Qodiriyah (TNQ) beserta produk terapinya seperti balai pengobatan ketagihan dadah, yang bernama 'Inabah'. Maka, yang dapat kita lihat dari segi penyebaran produk Suryalaya adalah bermunculannya Jama'ah-jama'ah tariqat (Talqin) dan Inabah di berbagai daerah di Indonesia, bahkan sampai ke luar negeri seperti Singapura, Malaysia, Brunei, bahkan Australia.

Tradisi pengindukan pun tidak terjadi bagi pesantren-pesantren modern seperti Al-Furqon dan Persis. Demikian karena di sini kesetiaan santri bukan pada pesantren tertentu saja, tetapi pada ajaran yang dipegang oleh organisasi. Modelnya, di sini, bukanlah pesantren, atau kyai, tetapi organisasi itu sendiri. Misalnya, walaupun ada tradisi pengindukan, namun karena ada semangat kesetaraan pada para anggota Persis, maka pengindukan tidak begitu penting pada pesantren Persis. Begitu pula halnya dengan para anggota Muhammadiyah.

Tabel 2

Perbandingan Sampel Pesantren di Kab. Tasikmalaya.

\begin{tabular}{|c|c|c|c|c|c|c|}
\hline \multirow[t]{2}{*}{ Perihal } & \multicolumn{2}{|c|}{ Salafi } & \multicolumn{2}{|c|}{ Khalafi } & \multicolumn{2}{|c|}{ Kombinasi } \\
\hline & Besar & Kecil & Besar & Kecil & Besar & Kecil \\
\hline Nama & $\begin{array}{l}\text { Miftahul } \\
\text { Huda }\end{array}$ & $\begin{array}{l}\text { Asy- } \\
\text { Syahidiyah }\end{array}$ & Al-Furqon & Persis & Suryalaya & Ar-Riyadh \\
\hline $\begin{array}{l}\text { Tahun } \\
\text { Didirikan }\end{array}$ & 1967 & 1960-an & 1992 & 1979 & 1905 & 1930-an \\
\hline Pendiri & $\begin{array}{l}\text { KH. } \\
\text { Choer } \\
\text { Affandy }\end{array}$ & $\begin{array}{l}\text { KH. } \\
\text { Syuhada } \\
\text { Al-Murtazi }\end{array}$ & Muhammadiyah & Persis & $\begin{array}{l}\text { Syech } \\
\text { Abdullah } \\
\text { Mubarok }\end{array}$ & $\begin{array}{l}\text { KH. } \\
\text { Fachruddin }\end{array}$ \\
\hline $\begin{array}{l}\text { Kyai } \\
\text { Sekarang }\end{array}$ & $\begin{array}{l}\text { KH. } \\
\text { Asep } \\
\text { Maoshul } \\
\text { Affandy }\end{array}$ & $\begin{array}{l}\text { KH. } \\
\text { Alfaryzant }\end{array}$ & $\begin{array}{l}\text { KH. Asep } \\
\text { Hidayat, Lc. }\end{array}$ & $\begin{array}{l}\text { Ust. Cece } \\
\text { Syamsudin }\end{array}$ & $\begin{array}{l}\text { KHA. } \\
\text { Shohibulwafa } \\
\text { Tajul Arifin }\end{array}$ & $\begin{array}{l}\text { KH. Asep } \\
\text { Bakhtiar } \\
\text { Rifai }\end{array}$ \\
\hline $\begin{array}{l}\text { Jumlah } \\
\text { Santri }\end{array}$ & 2500-an & 20 & 356 & 250 -an & 2175 & 400-an \\
\hline $\begin{array}{l}\text { Jumlah } \\
\text { Guru }\end{array}$ & 89 & 1 & 60 & 50 & 172 & 100 -an \\
\hline $\begin{array}{l}\text { Jumlah } \\
\text { Sekolah }\end{array}$ & - & - & - & 1 & 3 & 1 \\
\hline $\begin{array}{l}\text { Jumlah } \\
\text { Madrasah }\end{array}$ & - & - & 3 & 1 & 3 & 1 \\
\hline $\begin{array}{l}\text { Jumlah } \\
\text { Perguruan } \\
\text { Tinggi } \\
\end{array}$ & $\begin{array}{l}1 \\
\text { (Ma'had } \\
\text { Aly) }\end{array}$ & - & - & - & 2 & - \\
\hline $\begin{array}{l}\text { Jumlah } \\
\text { Mahasiswa }\end{array}$ & 100 -an & - & - & - & 684 & - \\
\hline $\begin{array}{l}\text { Jumlah } \\
\text { Pensyarah }\end{array}$ & 10 & - & - & - & 152 & - \\
\hline Koperasi & Ada & - & - & - & Ada & - \\
\hline
\end{tabular}


ARTIKEL

\begin{tabular}{|l|l|l|l|l|l|l|}
\hline Bengkel & Ada & - & - & - & Ada & Ada \\
\hline Sawah & Ada & & & & Ada & \\
\hline Radio & Ada & & & & Ada & \\
\hline $\begin{array}{l}\text { Bantuan } \\
\text { Pemerintah }\end{array}$ & Ada & - & Ada & Ada & Ada & Ada \\
\hline
\end{tabular}

Pola Manajemen Pesantren

Seperti disebutkan sebelum ini bahwa pesantren itu dipunyaikyai, maka pola manajemennya adalah tergantung pada kyai tersebut. Di sinilah kyai disebut sebagai berada dalam pola kepemimpinan tunggal. Dikatakan bahwa, misalnya, di Pesantren Miftahul Huda, Kyai Choer Affandi (Uwa Ajengan) adalah penggagas, pencari tanah, pembina, pengurus, pengajar, dan pemimpin. Demikianlah sehingga sampai awal tahun 1986, seluruh kegiatan pesantren dikendalikan secara terus oleh Uwa. Uwa sendiri, misalnya, sering memimpin senam kesegaran jasmani setiap hari Jumat.

Setelah kyai melakukan kaderisasi, barulah ada semacam delegasi otoritas (delegation of authority). Kaderisasi ini, terutama, tentu saja, adalah ditujukan kepada keluarganya sendiri, yang kemudian membentuk apa yang disebut sebagai Dewan Kyai. Di Pesantren Miftahul Huda, misalnya, setelah tahun 1986, Uwa secara berangsur membatasi dirinya. Sejak itu manajemen pesantren sebagian besar didelegasikan pada Dewan Kyai. Dewan Kyai, pada mulanya, adalah pembantu Uwa yang dibentuk dan diarahkan sesuai dengan bakat dan kepribadian masing-masing. Setahap demi setahap peranan Dewan Kyai tersebut diperbesar. Demikianlah sehingga ketika Uwa meninggal, Dewan Kyaisudah mampu mengurusi pesantren.

Hal ini terjadi pula pada pesantren kombinasi (campuran tradisional dan modern). Ini karenamemang pesantren kombinasi itu berasal dari pesantren tradisional. Bedanya ialah pesantren kombinasi itu telah melakukan adaptasi dengan kemodernan. Namun dalam hal manajemen, pesantren kombinasi itu masih memakai pola manajemen tradisional, yaitukyai sebagai yang dominan, yang kemudian mewakilkan tugas-tugasnya pada keluarganya yang pada akhirnya keluarga itulah yang mengurusi pesantren. Hal ini terjadi, misalnya, di Pesantren Suryalaya dan Pesantren Ar-Riyadh Leuwisari yang masing-masingnya telah mempunyai suatu organisasi yang disebut yayasan (foundation).

Berbeda dengan pesantren tradisional, pesantren modern sejak awal sudah memakai pola manajemenmodern. Ciri-ciri pola manajemenmodern, seperti, spesialisasi peranan (division of labor) telah dilaksanakan di pesantren modern. 
Demikian pula telah ada penggunaan media-media seperti penggunaan bel (dalam pemberitahuan kepada santri),tv, video, dll. Kesetiaan pula adalah kepada program, dan bukan kepada kyai tertentu saja. Berikut ilustrasi yang digambarkan oleh salah seorang pengelola Pesantren Al-Furqon.

Ya Alhamdulillah kalau sekolah mah nggak ketinggalan. Karena anak itu di sini belajar dan belajar, meskipun ada yang otodidak, tetapi banyak juga yang disebabkan pengaruh lingkungan yang disiplin, tidak boleh keluar, ya terpaksa pada belajar. Sebenarnya kunci keberhasilannya sekolah disini adalah kuatnya disiplin. Ada orang tua yang minta izin ambil anak, kadang-kadang kita tolak, kita kasih arahan Pak ini anak besok mau ujian. Di sini kyainya saja harus ikut aturan. Misalnya, Ustadz Asep, pimpinan pesantren, mau ketemu anaknya, ya harus menunggu jadualnya, tidak seenak-enaknya saja. (Kode wawancara: C-3; Kode rekam: PIC_0358-0364.AVI).

Ciri lain yang membedakan antara pesantren tradisional dan modern adalah mengenai akuntabilitas. Pada pesantren tradisional, akuntabilitas publik itu tidak terjadi. Walaupun ada antara harta benda pesantren yang berasal dari wakaf masyarakat, namun orang pun sudah percaya pada kyai dan keluarganya untuk menguruskan pesantren berikut harta bendanya. Hal itu tidak terjadi pada pesantren modern, terutama yang berbasis organisasi keagamaan modern, seperti Muhammadiyah dan Persis. Di Pesantren Al-Furqon Muhammadiyah, akuntabilitas nampak apabila pihak yang mengurusi pesantren melaporkan pertanggungjawaban kepada pihak pimpinan Muhammadiyah Daerah Tasikmalaya dan kemudian pihak pimpinan tersebut melaporkan kepada para anggota Muhammadiyah secara keseluruhan.

Ciri lain pula pada pesantren modern adalah efisiensi. Demi efisiensi, pergantian struktur manajemenakan terjadi secara periodik atau kapan-kapan saja apabila dirasa perlu. Pada pergantian ini nampaklah bahwa para kyai dan ustadzakan berlainan antara satu tahun ke tahun yang lain, tetapi program pesantren tetaplah sama. Perubahan orang ini bukannya membuat santri keluar dari pesantren dan membuat pesantren sepidari santri, seperti yang terjadi pada pesantren tradisional; justru hal itu bisa membuat santri-santri datang dan orang tua santri lebih percaya karena pesantren tersebut lebih mengutamakan program pesantrennya berbanding pada dominasi orang-orang tertentu saja. Inilah yang terjadi pada pesantren-pesantren modern di Kab. Tasikmalaya seperti Al-Furqon dan Pesantren Persis. 
Pesantren ini memang didirikan oleh organisasi ya, Muhammadiyah. Jadi walaupun pada mulanya ada muwakif, ada ustadz yang mendirikan, tetapi pesantren ini menjadi milik dan menjadi program Muhammadiyah. Jadi kita harus ikut. Bukan ikut pada orang per orang, Karena orang itu kan suka berubah. Misalnya, ustadz yang mendirikan, mendirikan lagi pesantren baru, ya kita ganti. Dulu pun pada mulanya bukan hanya satu kyai, tetapi banyak ustadz berkumpul. Murid juga dikumpulkan baru dua puluh orang. Ya itulah karya kolektif, karya Muhammadiyah. (KodeWawancara: C-3; Kode rekam: PIC_0358-0364.AVI).

Pada tingkat perencanaan, secara umum pesantren memiliki rancangan yang sederhana, yakni bertumpu pada keyakinan kyai atas kemampuannya dalam membesarkan pesantren yang dipimpinnya sendiri. Jika kemudian pesantren tersebut banyak diminati oleh masyarakat, yang terbukti dengan jumlah santri yang belajar di pesantren ini, maka santri senior bertindak sebagai tenaga pengajar yang secara tidak langsung ditunjuk oleh kyai dalam mewakili dirinya untuk mengajar santri pada tingkat pemula atau dasar. Hal seperti ini telah menjadi tradisi di setiap pesantren, khususnya di pesantren-pesantren di Kab. Tasikmalaya. Sebagai contoh, Wawan AlFarisi, 25 tahun, yang telah 10 tahun menjadi santri di pesantren Miftahul Huda Manonjaya, di samping ia sebagai santri senior di pesantren ini, ia juga merangkap sebagai wakilketua santri. Beliau ini telah 3 tahun diberi tugas oleh kyainya untuk bertindak sebagai ustadz dan membimbing santri-santri pada tingkat pemula, pada mata pelajaran bahasa Arab. Berikut kesaksian santri yang menjadi ketua bagian pendidikan Miftahul Huda.

Pesantren ini sudah memakai sistem kelas. Kan kelas itu semuanya ada 42 kelas. Tiap satu kelas ada dua orang guru. Guru yang utama dan asistennya. Semuanya ada delapan puluh lima. Pemilihan guru dilakukan oleh Dewan Kyai. Santri-santri senior yang terpilih biasanya terus mengajar di sini sampai dia menikah atau kembali ke kampung halamannya. Santri yang senior memang dilatih untuk bisa menguruskan seluruh kegiatan kepesantrenan, bukan hanya mengajar. Disadari memang harus ada regenerasi. Jangan sampai sudah tidak ada pimpinan tidak ada yang meneruskan. Santri dibagi-bagi sesuai kecenderungan bakat masing-masing, ada yang bagian keamanan, pendidikan, dakwah, dan seterusnya. (KodeWawancara: A-8; Kode Rekam: PIC_0747-0751.AVI).

Penunjukan ini membuktikan bahwa pada tingkat perencanaan, pesantren memang memiliki keunikan tersendiri di samping sederhana, namun sangat efektif dalam menumbuhkan tingkat kompetensi, untuk meningkatkan pengetahuan dan 
wawasan santri itu sendiri di bidang pengetahuan keagamaan Islam yang digelutinya, yakni dengan penunjukan kepada santri senior yang tentunya dianggap mempunyai kemampuan untuk bisa mengajar. Dari sini terlihat pula, bahwa prosedur penunjukkan sebagai tenaga pengajar itu di samping mengandalkan ketuaan (senioritas), juga melihat kemampuan santri yang bersangkutan.

Pada tingkat pemilihan dan orientasi, jelas sekali penunjukan santri senior, misalnya sebagai wakil kyai untuk mengajar suatu mata pelajaran, berorientasi pada peningkatan sumber daya manusia santri itu sendiri, yang diharapkan pada suatu saat kelak, santri tersebut diharapkan bisa menjadi kyai atau bahkan mampu mendirikan pesantren di tempat kelahirannya sendiri. Hal ini telah terbukti misalnya KH. Effendy yang alumni pesantren Miftahul Huda, sejak ditunjuk menjadi wakil ustadz selama belajar di pesantren asal beliau belajar ia kemudian mampu mendirikan pesantren sendiri dengan nama yang sama yaitu pesantren Miftahul Huda III di Kota Tasikmalaya. Pesantren ini telah memiliki santri kurang lebih 400 orang santri. Keadaan demikian pun terjadi pada santri-santri alumni pesantren yang lain di Kab. Tasikmalaya, seperti alumni pesantren Ar-Riyadh; mereka telah mampu mendirikan pesantren sendiri, yang biasanya didirikan di tempat kampung mereka berasal.

Pada tingkat pengorganisasian untuk pengembangan sumber daya manusia, adalah nampak bahwapesantren mengandalkan bentuk-bentuk emosi keagamaan dan kekelompokan. Misalnya untuk membangun komunikasi antara sesama alumni suatu pesantren, maka diadakanlah temu alumni yang biasanya diselenggarakan setahun sekali. Praktek ini telah lama dilaksanakan di pesantren Miftahul Huda, Manonjaya dengan adanya suatu organisasi bernama Himpunan Alumni Miftahul Huda (HAMIDA). Artinya langkah koordinasi semacam ini sudah berciri modern. Demikian pula pengorganisasian pada tingkat santri, telah berdiri semacam himpunan pelajar. Instrumen modern dalam pengorganisasian untuk meningkatkan kualitassumber daya manusia pesantren benar-benar telah memasuki pesantren, yang dalam prakteknya, menggunakan azas musyawarah dan mufakat dalam merumuskan suatu rencana ke depan. Berikut wawancara dengan salah seorang pimpinan himpunan alumni Pesantren Miftahul Huda.

Abdi kalebet pengurus yayasan pesantren, kalebet dewan pimpinan, lebet kulawargi Uwa Ajengan. Sareng abdi ge kalebet pimpinan HAMIDA (Himpunan Alumni Miftabul 
ARTIKEL

Huda). Dina raraga ngabimpun kakiatan pasantren sareng sarana silaturabmi, bimpunan alumni didirikeun. Kangge pusat informasi, sareng sagala rupi kamaslahatan. Biasana ba'da boboran ngarempelna alumni teh. Di dieu kangge musyawarah.

[Saya termasuk pengurus yayasan pesantren, termasuk dewan pimpinan, masuk keluarga Uwa Ajengan. Saya juga termasuk pimpinan HAMIDA (Himpunan Alumni Miftahul Huda). Dalam rangka menghimpun kekuatan pesantren juga sarana silaturahim, himpunan alumni pun didirikan. Untuk pusat informasi, juga untuk berbagai kebaikan. Biasanya sehabis lebaran berkumpulnya para alumni di sini untuk bermusyawarah.] (KodeWawancara: A-1; Kode rekam: PIC_0614-0615.AVI).

Pada tingkat promosi, pesantren melakukan usaha kaderisasi kepemimpinan pesantren melalui pembinaan para santri yang telah dianggapnya senior, baik dalam ilmunya maupun usianya. Apabila menurut anggapan kyai seseorang itu telah memenuhi persyaratan, biasanya diberi kepercayaan untuk tampil sebagai wakil kyai dalam hal pemberian pelajaran, dan bahkan memimpin pesantren baru yang menjadi cabangnya. Oleh karena itu, kegiatan penempatan sumber daya manusia pada kedudukan atau "jabatan” tertentu, pesantren melakukannya untuk kepentingan yang sifatnya fungsional maupun struktural. Dalam merekrut calon yang telah dianggap memenuhi syarat untuk dipromosikan, kyai biasanya lebih mendahulukan orang dalam (insider) dibanding orang luar (outsider).

Janten pami teu ka kulawargi ka saha deui nitipkeun ajaran teh. Janten Uwa ngawulangkeun sagala rupi kitab nu ku anjeunna dikuasai ka murid-muridna, terutami ka kulawargina. Sagala kitab kedah dikuasai. Mana wae kelas anu kosong kedah dieusian. Kedah siap we ngajar naon-naon oge. Eta tugas the utamina kangge kulawargina. Margi kulawargina pisan nu kedah ngalanggengkeun pasantren. Anu sanes kulawargi mah mung ngabantosan wungkul. Pami pasantren kanu saneskeun, pasti bakal aya pacogregan, paboyong-hoyong.

Jadi kalau bukan pada keluarga kepada siapa lagi menitipkan ajaran ini? Jadi Uwa mengajarkan berbagai kitab yang beliau kuasai kepada murid-muridnya, terutama kepada keluarganya. Berbagai kitab mesti dikuasai. Mana saja kelas yang kosong harus diisi. Harus siap mengajar apa-apa saja. Itu juga tugas terutama buat keluarganya. Sebab adalah keluarganya yang harus melestarikan pesantren. Yang bukan keluarga itu hanya membantu. Jika pesantren diberikan kepada yang lain, tentu akan terjadi pertikaian, semua pada mau menguruskannya.](Kode Wawancara: A-1; Kode Rekam: PIC_06140615.AVI).

Pada tingkat pengembangan karier, yang kaitannya dengan pemberdayaan alumni pesantren, biasanya kyai mengajak para santri seniornya turun ke desa-desa memberikan ceramah keagamaan. Maka lambat laun santri tersebut diterima oleh 
masyarakat tertentu untuk menjadi guru di tempat mereka. Hal itu terus berlanjut pada perencanaan pendirian pesantren secara resmi. Biasanya pada tahap awal pendirian pesantren baru ini, gurunya diundang untuk memberi kata sambutan dan pengharapan atas kehadiran pesantren baru ini, agar kelak di masa mendatang menjadi pesantren besar. Kyai Effendy, ketika mendirikan pesantren Miftahul Huda III, sangat merasakan peranan gurunya yaituKyaiChoer Affandi, sehingga pesantren ini lambat laun diterima oleh masyarakat di sekitarnya. Bahkan santri pemula yang mendaftar ke Miftahul Huda, didorongnya untuk mendaftar di pesantren baru ini yang dipimpin oleh muridnya sendiri. Berikut kata-kata Kyai Effendy sendiri:

Saatos nikeah Uwa ngidinan ngamukimkeun abdi. Nya taun 1974 teh ngadirikeun we pasantren ieu. Ti enol ieu oge. Carana donasi, sa-Tasik-Ciamis. Uwa kantenan ngabantos. Da peletakan batu pertamana ge ku Uwa. Uwa ge ngajak sasaha nu ngaguru ka anjeunna pikeun ngawangun pasantren ieu. Janten urang pasantren mah silib rojong. Uwa ge ngamodalan santri. Janten santrina sapalih dipiwarang ngiring ka abdi.

[Setelah saya menikah Uwa mengizinkan saya untuk bermasyarakat. Ya pada tahun 1974 didirikan saja pesantren ini. Dari nol ini juga. Caranya dengan sumbangan, se-Tasik-Ciamis. Uwa tentu saja membantu. Kan peletakan batu pertamanya juga oleh Uwa. Uwa juga mengajak setiap orang yang berguru kepadanya untuk membantu membangun pesantren ini. Jadi orang pesantren itu bahu membahu. Uwa juga memberi modal santri. Jadi santrinya sebagian disuruh Uwa untuk mengikuti saya ke sini.] (Kode wawancara: H-1; Kode rekam: PIC_1112-1114.AVI).

Dengan demikian, pada intinya alumni pesantren tidak dibiarkan oleh gurunya tanpa bimbingan setelah mereka menyelesaikan studinya. Jadi pemberdayaan sumber daya manusia pesantren pada tingkat ini tetap saja dilakukan oleh pesantren itu sendiri, walaupun sebenarnya antara alumni dan pesantren itu tidak mempunyai kewajiban apa-apa yang secara tertulis mengharuskan membimbing mereka setelah selesai pengajian. Namun demikian, karena besarnya hubungan keterikatan kelompok, maka pada tingkat pengembangan karier pun atau penentuan garis hidup, santri tidak lepas dari perhatian pesantrennya sendiri. Hal inilah yang membedakan dengan sekolah-sekolah modern, di mana institusi pendidikan tidak mempunyai kewajiban baik secara moral maupunlegal untuk menyerap alumninya setelah selesai studi. Mereka dibiarkan berkreasi sendiri menentukan langkah hidupnya di luar sekolah setamat belajar. 
Hal ini dapat menciptakan iklim kebersamaan dalam organisasi di dunia pesantren, antara guru dan murid atau atasan dan bawahan sangat menunjang keberhasilan dalam peningkatan sumber daya manusia pesantren. Demikian pula konflik yang bersifat individual bisa terkikis habis. Karenakepemimpinan di dunia pesantren tertumpu pada ketaatan hubungan guru-murid yang dilandasi akhlak yang luhur.

\section{Institusi Pembantu}

Seperti dijelaskan di atas, pihak pesantren sudah menyadari akan perlunya pendelegasian otoritasdari pimpinan pesantren kepada institusi-institusi pembantu untuk memperlancar jalannya sistem kepesantrenan. Di Pesantren Miftahul Huda, pengelolaan Pesantren sepeninggalan Uwa Ajengan dilakukan secara bersama-sama oleh Dewan Kyai, yang terdiri dari anak-anak, menantu, cucu dan cucu menantu Uwa Ajengan, yang telah menamatkan seluruh program pendidikan di Pondok Pesantren Miftahul Huda. Berikut adalah pernyataan salah seorang anggota Dewan Kyai.

Saleresna dewan kyai sareng dewan guru teh sebatan wungkul. Da ari dina praktekna mah Uwa teh tangtos cape pisan pami sagala ku nyalira. Nya aya nu ngabarantos. Boh kulawargina, boh santrina. Ari kulawargina mah tangtos kedah tanggel waler kana sagala rupi kapasantrenan. Nya disebat we dewan kyai. Sedengkeun santri-santrina mah, terutami nu senior nya ngabantos-bantos, terutamina dina ngawulang. Janten we disebat dewan guru.

[Sebetulnya dewan kyai dan dewan guru itu hanyalah sebutan. Karena pada prakteknya Uwa memang sudah sangat letih apabila segala sesuatu diperbuat sendiri. Maka ada lah yang membantu. Baik keluarganya, ataupun santrinya. Keluarganya tentu harus bertanggung jawab terhadap segala bentuk kepesantrenan. Itulah yang disebut dewan kyai. Sedangkan santri-santrinya, terutama yang senior hanya membantu, terutama dalam mengajar. Jadilah disebut dewan guru.] (Kode wawancara: A-1; Kode rekam: PIC_06140615.AVI).

Pada awalnya, keberadaan Dewan Kyai merupakan pembantu Uwa Ajengan yang dibentuk dan diarahkan sesuai dengan bakat dan kepribadian masing-masing. Sehingga dalam tubuh dewan tersebut terjadi spesialisasi yang sedikit demi sedikit menjadi besar. Kini, Dewan Kyai ini dipimpin oleh Kepemimpinan Ganda (Double Leadership), yaituKyai Asep Ahmad Maoshul Affandy dan Kyai Abdul Aziz Affandy (dua putera Almarhum Uwa Ajengan). Selain oleh keluarga Almarhum, keduanya juga 
dibantu oleh santri Khodimul Ma'had/Pengabdian, yaitu santri senior yang telah menyelesaikan pengajian tahun akhir dan mengikuti wisuda.

Hal yang sama terjadi di Pesantren Suryalaya. Pada awalnya, pesantren ini didominasi oleh profil Kyai Abdul Wafa' Tajul Arifin. Kemudian, untuk membantu tugasnya, Abah Anom dengan beberapa tokoh pondok pesantren pada tanggal 11 Mac 1961 mendirikan Yayasan Serba Bakti. Kegiatan utama yayasan ialah membina ikhwan dalam bidang tarekat dan sosial. Yayasan ini memiliki 56 perwakilan di kabupaten dan kota yang tersebar di seluruh Indonesia. (Dari Satu Abad Pondok Pesantren Suryalaya, 2005).

Demikianlah, maka pesantren pun menuntut sistem pengaturan kerja yang semakin modern. Dengan kata lain, pesantren perlu modernisasi. Hal ini dilakukan, misalnya, dengan membentuk beberapa organisasi untuk melaksanakan programprogram baik untuk di dalam pesantren, maupun di luar pesantren. Modernisasi itu memang diperlukan oleh pesantren. Sekarang, hampir semua pesantren mempunyai asas legal, seperti di bawah yayasan. Hal ini misalnya digunakan untuk keperluan apasaja yang berhubungan dengan legalitas formal. Bahkan apabila ada bantuan dari pihak pemerintah, misalnya, biasanya dimintai asal legalitas formal tersebut.

Selain pembuatan yayasan, institusi-institusi pembantu di dalam pesantren pun dibuat guna memperlancar kegiatan kepesantrenan. Di Pesantren Miftahul Huda, organisasi-organisasi yang dibuat antara lain ialah organisasi murid pesantren Miftahul Huda, Badan Pembina Pondok Pesantren Miftahul Huda (BP3), Himpunan Alumni Pesantren Miftahul Huda (HAMIDA), dan Koperasi Pesantren Miftahul Huda (KOMIDA).

Berikut ialah peringkatan manajemen pesantren yang dapat dilihat pada Pesantren Miftahul Huda.

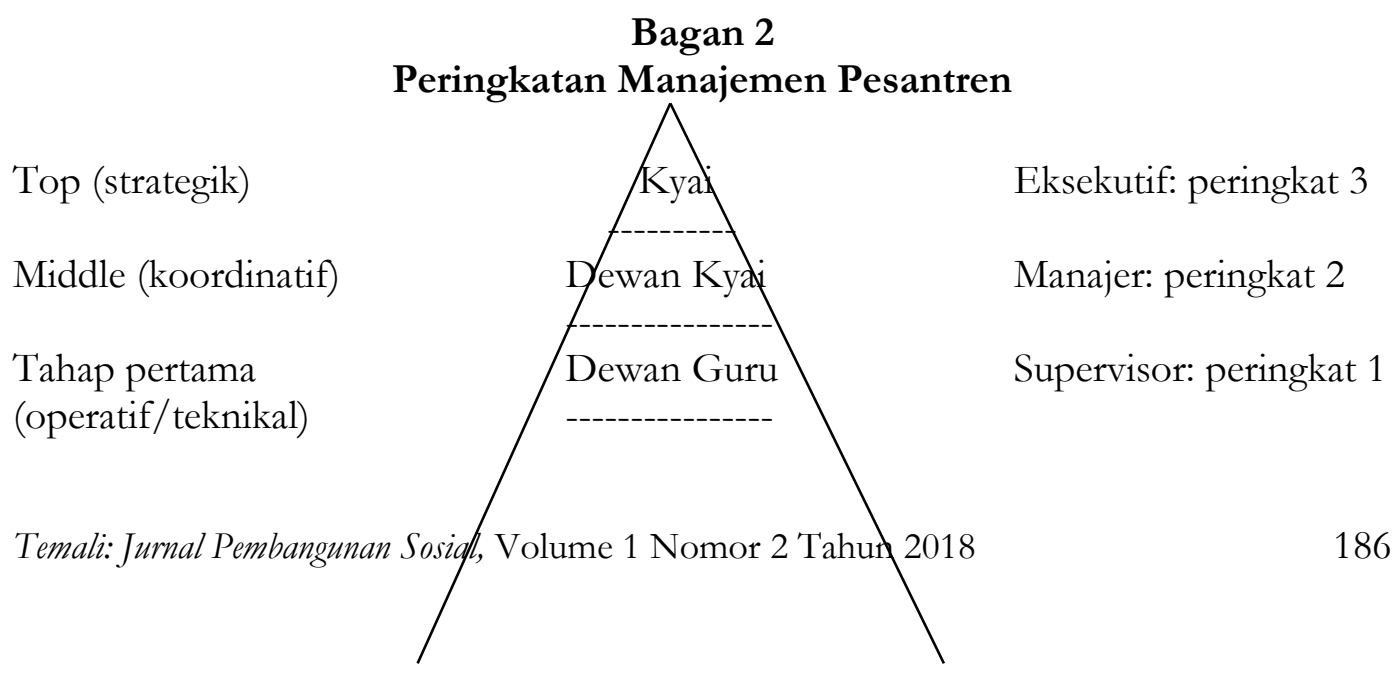


ARTIKEL

Pekerja Santri Karya

Sumber: Huse, 1979

\section{Manajemen Dana}

Sebagaimana diketahui, pesantren terutama mempunyai masjid dan rumah kyai. Namun apabila kita hendak melihat keseluruhan, nampak bahwa pondok santri sangatlah diperlukan. Semakin modern semakin banyak pula fasilitas yang diperlukan seperti bangunan-bangunan kantor, kamar-kamar air, bahkan diperlukan pula semacam rumah untuk para tetamu atau mereka yang datang secara sementara.

Dapat dilihat bahwa yang terlengkap di antara yang diteliti adalah Pesantren Suryalaya. Demikian karena pesantren ini memiliki banyak muwaqif (pemberi wakaf). Pesantren Suryalaya telah mampu memberi kenyamanan kepada para santrinya dalam hal fasilitas yang serba lengkap dan serba bersih.

Sementara di tempat lain, seperti di Miftahul Huda, bangunan gedung masihlah dirasakan kurang mengingat santri yang begitu banyak dengan sarana yang tersedia sangat tidak memadai. Oleh karena itu, masjid dan surau pun selalu menjadi tempat belajar dan tidur. Begitu pun rumah para ustadz seringkali digunakan untuk belajar dan tidur. Dengan demikian, pesantren memang institusi yang terus berkembang, yang dengan demikian masih selalu perlu untuk diuruskan dari berbagai hal, termasuk dalam hal manajemendana.

Dari segi manajemendana, pada dasarnya pesantren perlu ada kemampuan sendiri untuk membiayai semua keperluannya. Yaitu pertama-tama dari keuangankyai dan keluarganya, kemudian dari santri, dari penderma baik tetap ataupun tidak tetap. Para penderma itu biasanya ialah orang-orang yang mempunyai keterkaitan dengan pesantren, baik sebagai alumni, orang tua santri, ataupun orang-orang yang simpati terhadap kyai atau pesantren.

Bantuan daripemerintahmemang suka datang menawarkan kepada pesantren. Namun tidak semua pesantren menerima, dengan alasan-alasan yang mereka sendiri yang tahu. Banyak pula dari pesantren itu yang menerima bantuan pemerintah. Pesantren Suryalaya, misalnya, adalah salah sebuah pesantren yang paling banyak 
ARTIKEL

mendapatkan bantuan pemerintahbaikia berbentuk bangunan, laboratorium, maupun berbentuk bantuan orang, seperti guru bantuan pemerintah yang digaji oleh pemerintah namun mengajar di sekolah yang dipunyai pesantren.

Dariangket yang disebarkan kepada responden, yaitupertanyaan no. 18, yang berbunyi, "Sumber pembiayaan pesantren yang diketahui adalah dari: (jawaban boleb lebih dari satu)" diketahui bahwa dalam asal-usul dana pesantren pada masa kesekarangan iurandari santri menduduki peringkat pertama jawaban (100\%), kemudian barulah dari wakaf-wakaf (67\%), sumbangan orang tua santri (61\%), usahausaha pesantren (49\%), bantuan dari masyarakat (41\%), bantuan daripemerintah (23\%), dan dari tamu-tamu yang datang ke pesantren (20\%).

Tabel 3

Jawaban Responden Tentang Sumber Keuangan Pesantren

\begin{tabular}{|l|r|r|}
\hline \multicolumn{1}{|c|}{ Sumber Keuangan Pesantren } & \multicolumn{1}{c|}{$\begin{array}{c}\text { Jumlah } \\
\text { Jawaban }\end{array}$} & \multicolumn{1}{c|}{$\%$} \\
\hline a. Sumbangan orang tua santri & 153 & 61 \\
\hline b. Wakaf-wakaf & 170 & 67 \\
\hline c. Iuran para santri & 252 & 100 \\
\hline d. $\quad$ Bantuan Pemerintah & 59 & 23 \\
\hline e. $\quad$ Bantuan Masyarakat & 104 & 41 \\
\hline f. Usaha-usaha pesantren & 124 & 49 \\
\hline g. Dari tamu-tamu yg datang ke pesantren & 50 & 20 \\
\hline
\end{tabular}

Sumber: Hasil Angket Pertanyaan No. 18. N=252.

Sementara itu, dari segi penggunaan dana, apa yang diketahui oleh pendapat umum adalah bahwaia terutama dilaksanakan manajemennya oleh keluarga kyai (92\%), kemudian oleh kyai dan pimpinan pesantren (65\%), dan terakhir oleh yayasan (61\%). Prioritasjawaban tersebut diketahui dari jawaban atas pertanyaanangket no. 19 yang berbunyi, "Pelaksanaan penggunaan dana pesantren dilakukan oleh:(jawaban boleh lebih dari satu)." Jelaslah bahwasekarang ini keluarga kyai mengambil peranan yang cukup besar dalam penggunaan dana pesantren. Demikian karena semakin besar urusan pesantren, mesti semakin banyak pula yang menguruskannya. Dan yang pertama mengambil peranan manajemen tersebut ialah keluarga kyai.

\section{Tabel 4}

Jawaban Responden Tentang Pelaksanaan Penggunaan Dana

\begin{tabular}{|c|c|c|}
\hline Pelaksanaan Penggunaan Dana & $\begin{array}{c}\text { Jumlah } \\
\text { Jawaban }\end{array}$ & $\%$ \\
\hline
\end{tabular}




\begin{tabular}{|l|r|r|}
\cline { 2 - 3 } a. Kyai dan pimpinan pesantren & 163 & 65 \\
\hline b. Keluarga Kyai & 231 & 92 \\
\hline c. Yayasan & 153 & 61 \\
\hline d. Tidak tahu & & 0 \\
\hline
\end{tabular}

Sumber: Hasil AngketPertanyaan No. 19. N=252.

Sebagai catatan lain, sebenarnya, apabila sudah dipercaya oleh masyarakat, pembangunan pesantren pun berjalan secara berkesinambungan, dari mulai hanya pesantren, kemudian mempunyai MTs (Madrasah Tsanawiyah), kemudian TK, MA (Madrasah Aliyah), SMK (Sekolah Menengah Kejuruan), bahkan perguruan tinggi. Demikian karena pesantren selalu terbuka dalam menerima zakat, infaq, sodaqoh, hibah, wakaf, hadiah, dan sebagainya yang bersifat halal dari siapapun. Di situlah pesantren telah menjadi seperti sebuah pasar di mana ada yang menjual dan ada yang membeli, dan seperti institusi sosial di mana ada yang mengambil dan ada yang memberi (take and give).

Ramainya masyarakat ikut serta dalam proses take and give tadi memang sangat terasa pada pesantren-pesantren modern dan kombinasi. Demikian karena pesantrenpesantren tersebut telahmemakai cara-cara modern dalam manajemen pesantren. Sebab lain ialah bahwa mereka lebih dapat beradaptasi dengan kemodernan. Pesantren-pesantren tradisional agak lambat dalam proses pembangunan karena mereka sedikit agak mengisolasi diri dari kemodernan. Berikut ialah hasil wawancara dengan Kepala Sub Bagian Agama, Seksi Kesejahteraan Rakyat, Pemerintah Daerah Kab. Tasikmalaya.

Sebagai pemerintah, kami ingin melakukan modernisasi pesantren. Demikian itu supaya pesantren dapat mengikuti perkembangan zaman. Kami memberikan bantuan uang pada pesantren-pesantren yang lagi membangun. Kami pun menyelenggarakan diklat-diklat, tentang manajemen, diklat protokoler, dan sebagainya. Sebetulnya sudah banyak pesantren yang membuka diri, terhadap dinas-dinas pemerintahan, terutama pesantrenpesantren yang membuka sekolah atau madrasah. Tetapi, memang masih ada pesantren-pesantren yang tidak menyelenggarakan pendidikan formal atau yang disebut pesantren salafiyah, terutama yang di pelosok-pelosok desa yang belum mau bekerja sama dengan pemerintah. (Kode Wawancara: G-2; Kode Rekam: PIC_1101-1102.AVI). 
Lalu bagaimana tanggapan pihak pesantren tradisional terhadap modernisasi tersebut? Berikut hasil wawancara dengan kyai pesantren tradisional di kaki Gunung Talagabodas.

Pami ngemut perkembangan zaman, memang ketimbang ayeuna anu kaluaran ti sakola wungkul, tokoh-tokoh masyarakat teh anu kaluaran pasantren mah langkung sae, pami disebat erem tea mah gaduh erem. Berarti untuk kemaslahatan zaman, urang pasantren kedah ngagaduhan ijazah anu diakui ku pihak-pihak pekerjaan formal. Bade ngadamel sakola nya kumaha, margi teu aya waragad, kan sanes ngempelkeun guru wungkul, kan kedah ngadamelan bangku sakola, sareng sagala rupi. Sementawis kan bantuan pamarentah teh teu ka sadaya pasantren. Rupina mah digilir. Masyarakat oge di pasisian mah teu acan haroyong sakola sapalih mah. Abdi siap wae ngadamel sakola, namung kedah aya anu ngokolotan. Margi abdi ge lulusan pasantren nu teu aya sakolaan, janten teu apal kumaha carana ngadamel sakola teh.

[Kalau mengingat perkembangan zaman, memang berbanding mereka yang hanya keluaran sekolah, tokoh-tokoh masyarakat yang keluaran pesantren memang lebih bagus, kalau disebut punya rem, mereka itu punya rem. Berarti untuk kemasalahatan zaman, orang pesantren mesti punya ijazah yang diakui oleh pihak-pihak (yang menawarkan) pekerjaan formal. Mau membikin sekolah ya bagaimana, sebab tidak ada fasilitas, kan bukan hanya mengumpulkan guru saja, kan mesti membuat meja-kerusi sekolah, dan segala macam. Sementara bantuan pemerintah itu tidak ke semua pesantren. Nampaknya bantuan itu digilir (satu per satu). Masyarakat juga di pinggiran itu masih belum mau sekolah sebagian itu. Saya siap membuat sekolah, tetapi mesti ada yang membantu membimbing. Sebab saya juga lulusan pesantren yang tidak ada sekolahnya, jadi tidak tahu harus bagaimana caranya membuat sekolah.](Kode Wawancara: B-2; Kode Rekam: PIC_0530-0535.AVI).

\section{Kesimpulan}

Menjawab permasalahan kajian mengenai bagaimana pola manajemen pesantren sebagai institusi sosial dan pembangunan masyarakat, berikut ialah kesimpulannya:

1. Pola manajemen pesantren terutama ditujukan untuk kelangsungan pesantren itu sendiri. Setelah itu, barulah manajemen yang ditujukan untuk keluar pesantren.

2. Kaderisasi adalah hal yang mutlak dilakukan di pesantren, karenaia merupakan usaha demi kesinambungan pesantren. Pola kaderisasi ini berbeda antara satu pesantren dengan pesantren lainnya, terutama bergantung kepada jenisnya. Pada pesantren tradisional, kaderisasi berlangsung terus darikyai kepada keluarganya. Selepas itu barulah kaderisasi kepada santri-santri yang 
ARTIKEL

mau mengabdi. Pada pesantren kombinasi kaderisasi dilakukan dengan caramendirikan yayasan (foundation) yang berisi keluarga kyai dan orang-orang yang mau berkhidmat kepada kyai. Pada pesantren modern pula, polanya adalah berlainan sama sekali. Di sini organisasi-organisasi induk pesantren lah yang menentukan. Dengan demikian, polanya adalah kolektif, bukan individual.

3. Bagaimanapun, pola-pola manajemenmodern seperti spesialisasi, efisiensi, promosi, dan sebagainya dilakukan pula oleh pesantren, termasuk oleh pesantren tradisional. Sebab tanpa manajemenmodern, pesantren akhirnya mengalami kebangkrutan seperti pesantren-pesantren tradisional kecil.

4. Untuk tujuan-tujuan pembagian tugas (division of labor), maka pesantren pun mendirikan institusi-institusi pembantu seperti Dewan Kyai, Dewan Guru, yayasan, dan sebagainya.

5. Sumber dana pesantren pada mulanya adalah berasal darikyai dan keluarganya. Namun, setelah berjalan, pesantren lebih banyak bertumpu pada iuran para santri, barulah dari lain-lain sumber termasuk orang tua santri, masyarakat, dan pihak pemerintah.

\section{DAFTAR PUSTAKA}

Abdullah, Taufik, "The Pesantren in Historical Perspective," in Abdullah, Taufik and Siddique, Sharon (eds.), Islam and Society in Southeast Asia, Singapore: Institute of Southeast Asian Studies, 1986.

Atlas Provinsi, 2016.

Badan Pusat Statistik Kabupaten Tasikmalaya, Kabupaten Tasikmalaya Dalam Angka, 2016).

Badan Pusat Statistik Tahun 2014, Hasil Pemutakhiran dalam rangka Pemilihan Presiden Tabun 2014.

Boeke J.H., The Structure of Netherlands Indian Economy, New York; Institute of Pacific Relations, 1942.

Chua, Yan Piaw, MetodePenelitian, Kuala Lumpur: Mc Graw Hill, 2006.

Depag R.I., Statistik Pendidikan Agama dan Keagamaan Tahun Pelajaran 2015-2016, Jakarta: Bagian Data dan Informasi Pendidikan, Direktorat Jenderal Pendidikan Islam, Departemen Agama, 2016. 
Depdikbud, Kamus Besar Bahasa Indonesia, Jakarta: Balai Pustaka, 1995.

Dhofier, Zamakhsari, TradisiPesantren, Kajian tentang Pandangan Hidup Kyai, Jakarta: LP3ES, Jakarta, 1983.

Korten, David C. and Alfonso, Felipe B. (eds.), Bureaucracy and the Poor: Closing the Gap, Singapore: McGraw-Hill International Book Company, Copyright by Asian Institute of Management, Makatai, Metro Manila, Philippines, 1981.

Madjid, Nurcholish, dkk. (ed.), Ensiklopedi Islam, Jilid IV, Jakarta: PT. Ichtiar Baru Van Hoeve, 1994.

Mansurnoor, Iik Arifin, Islam in an Indonesian World: Ulama of Madura, Yogyakarta: Gadjah Mada University Press, 1990.

Morrish, Ivor, The Sociology of Education: An Introduction, Unwin Education Books, Series Editor: Ivor Morrish, London: George Allen \& Unwin, (1972), $2^{\text {nd }}$ edition, 1978.

Mustari, Mohamad, and M. Taufik Rahman. Peranan pesantren dalam pembangunan pendidikan masyarakat desa. MultiPress, 2010.

Patton, Michael Quinn, Qualitative Research and Evaluation Methods, 3rd edition, London: Sage Publications, (1990), 2002.

Rahman, M. Taufiq. Glosari Teori Sosial. Bandung: Ibnu Sina Press. 2011.

Riggs, Fred W., Administration in Developing Countries: The Theory of Prismatic Society, Boston: Houghton Mifflin Company, 1964.

Salkind, Neil J., Exploring Research, 4th edition, New Jersey, US: Prentice Hall, (1991), 2000.

Satu Abad Pondok Pesantren Suryalaya: Perjalanan dan Pengabdian 1905-2005, Tasikmalaya: Yayasan Serba Bakti Pondok Pesantren Suryalaya, 2005.

Stalcup, R. J., Sociology and Education, Columbus, Ohio: C. E. Merrill, 1968.

Tohir Sh., H. Asep Moh. (ed.), Sisi Lain Pesantren Miftabul Huda, Tasikmalaya: Yayasan Pesantren Miftahul Huda, 1999.

Unang Sunardjo, RH., SH., Menelusuri Perjalanan Sejarah Pondok Pesantren Suryalaya, Tasikmalaya: Yayasan Serba Bakti Pondok Pesantren Suryalaya, 1995. 